\title{
Peranan Mata Kuliah Profesi Kependidikan dan Microteaching terhadap Kompetensi Profesional Mahasiswa PPL Fisika
}

\author{
Sohibun $^{1}$, Yeza Febriani ${ }^{2}$, Ina Maisaroh ${ }^{3}$ \\ 1, 2,3 Program Studi Pendidikan Fisika, Universitas Pasir Pengaraian. Email: bie.idsohib@gmail.com
}

Diterima: 1 Maret 2017. Disetujui: 22 Mei 2017. Dipublikasikan: Juni 2017

\begin{abstract}
The purpose of this study to determine the effect of the role of professional education and microteaching courses on the professional competence of physics class IV physics students. This study includes ex post facto research. The sample of this research is Field Supervisor (DPL) student of field practice (PPL) Physics Education department class IV that guide 18 students. Data collection using questionnaires and documentation. Data analysis techniques used are techniques of analysis of correlation and advanced analysis using coefficient of determination. The result of this research is that the influence of professional education and micro teaching subject to professional competence based on final score is included into very strong category that is equal to 1 with percentage of $100 \%$. Based on the questionnaire obtained the influence of professional education subject to professional competence enter into very strong criteria with calculation of correlation of 1 and percentage of 100\%. So that the subjects of teaching profession and micro teaching are very influential and actively participate in the professional competence of PPL Physics University of Pasir Pengaraian students.
\end{abstract}

\begin{abstract}
Abstrak
Tujuan dari penelitian ini untuk mengetahui pengaruh peranan mata kuliah profesi kependidikan dan microteaching terhadap kompetensi profesional mahasiswa PPL fisika angkatan IV. Penelitian ini termasuk jenis penelitian ex-post facto. Sampel dari penelitian ini adalah Dosen Pembimbing Lapangan (DPL) mahasiswa PPL Prodi Pendidikan fisika angkatan IV yang membimbing 18 mahasiswa. Pengumpulan data menggunakan angket dan dokumentasi. Teknik analisis data yang digunakan adalah teknik analisis kolerasi dan analisis lanjutan menggunakan koefisien determinasi. Hasil penelitian didapat bahwa pengaruh mata kuliah profesi kependidikan dan microteaching terhadap kompetensi profesional berdasarkan nilai akhir termasuk kedalam kategori sangat kuat yaitu sebesar 1 dengan persentase sebesar $100 \%$. Berdasarkan angket diperoleh pengaruh matakuliah profesi kependidikan terhadap kompetensi profesional masuk ke dalam kriteria sangat kuat dengan perhitungan korelasi sebesar 1 dan persentase sebesar $100 \%$. Sehingga mata kuliah profesi kependidikan dan microteaching sangat berpengaruh dan berperan aktif terhadap kompetensi profesional mahasiswa PPL Fisika Universitas Pasir Pengaraian.
\end{abstract}

Kata kunci: profesi kependidikan, micro teaching, kompetensi professional.

(C) 2017 URPI, FTK UIN Raden Intan Lampung

\section{PENDAHULUAN}

Fakultas Keguruan dan Ilmu Pendidikan (FKIP) Universitas Pasir Pengaraian mempunyai kegiatan akademik yang mewajibkan mahasiswanya untuk mengambil mata kuliah Program Pengalaman Lapangan (PPL). PPL merupakan program mata kuliah jurusan kependidikan yang bertujuan untuk mengasah kemampuan mahasiswa dalam mengajar secara profesional.
PPL dilakukan secara nyata di sekolah-sekolah yang telah bekerja sama dengan FKIP Universitas Pasir Pengaraian (UPP). PPL adalah salah satu ajang latihan bagi mahasiswa sebagai calon guru dalam menerapkan berbagai pengetahuan, sikap dan keterampilan dalam rangka pembentukan guru yang professional (Tim Revisi, 2016). Seorang guru profesional seharusnya memiliki dua unsur penting yaitu unsur kompetensi dan unsur prasyarat (Hendrayani, 2008). 
Kompetensi dipandang sebagai pilar kinerja dari suatu profesi (Suherman, 2014). Unsur kompetensi meliputi kompetensi ketrampilan proses dan penguasaan pengetahuan (akademik). Sementara unsur prasyarat yaitu potensi kepribadian atau kompetensi personal.

Mahasiswa yang dapat mengikuti program PPL adalah mahasiswa yang telah lulus mata kuliah syarat PPL yaitu Pengantar Pendidikan, Perkembangan Peserta Didik, Belajar dan Pembelajaran, Profesi Kependidikan, dan Microteaching. Mata kuliah tersebut diharapkan berpengaruh terhadap PPL, dikarenakan setiap praktik yang akan dilakukan dalam melaksanakan PPL berkesinambungan dengan mata kuliah tersebut.

Mata kuliah profesi kependidikan merupakan mata kuliah yang mempelajari tentang profesi seorang guru yang memahami kode etik sehingga dalam melaksanakan tugasnya sebagai guru tidak menyimpang dengan kode etik yang telah berlaku. Salah satu mata kuliah profesi pendidikan yaitu microteaching. Mata kuliah ini mengajarkan mahasiswa bagaimana cara mengajar dalam kelas dalam jumlah kecil.

Secara umum, kemampuan profesional yang harus dimiliki seorang guru antara lain: kemampuan penguasaan materi/bahan pelajaran, kemampuan merencanakan proses belajar mengajar, kemampuan mengelola program belajar mengajar, kemampuan dalam pelaksanaan proses belajar mengajar, kemampuan penggunaan media dan sumber belajar, dan kemampuan pelaksanaan evaluasi dan penilaian hasil belajar siswa. Selain itu, kemampuan tersebut harus didukung dengan berbagai ilmu pengetahuan, seperti psikologi, sosiologi, dan komunikasi (Muhroji \& Setyanto, 2016). Oleh karena itu, upaya peningkatan mutu pendidikan dan peningkatan kualitas tenaga kependidikan harus senantiasa dilakukan (Yamin, 2007).
Indikator penelitian pengaruh mata kuliah Profesi Kependidikan, Microteaching dan praktik PPL Mahasiswa Fisika FKIP terhadap Kompetensi profesional adalah sebagai berikut (Marno \& Idris, 2009):

Tabel 1. Indikator hubungan antara Profesi Kependidikan dengan Kompetensi Profesional

\begin{tabular}{llr}
\hline No & \multicolumn{1}{c}{ Indikator } \\
\hline 1 & $\begin{array}{l}\text { Penguasaan pada bidang studi yang } \\
\text { diajarkan }\end{array}$ \\
2 & Memahami keadaan diri siswa \\
3 & $\begin{array}{l}\text { Memahami prinsip-prinsip dan teknik } \\
\text { mengajar }\end{array}$ \\
4 & $\begin{array}{l}\text { Menguasai cabang-cabang ilmu } \\
\text { pengetahuan yang relevan dengan }\end{array}$ \\
& $\begin{array}{l}\text { bidang studinya } \\
5\end{array}$ & Menghargai profesinya \\
\hline
\end{tabular}

Tabel 2. Indikator hubungan antara micro teaching dengan Kompetensi Profesional

\begin{tabular}{ll}
\hline No & \multicolumn{1}{c}{ Indikator } \\
\hline 1 & $\begin{array}{l}\text { Menguasai materi, struktur, konsep, dan } \\
\text { pola pikir keilmuan yang mendukung } \\
\text { mata pelajaran yang diampu. }\end{array}$ \\
2 & $\begin{array}{l}\text { Menguasai standar kompetensi dan } \\
\text { kompetensi dasar mata pelajaran/bidang } \\
\text { pengembangan yang diampu. }\end{array}$ \\
3 & $\begin{array}{l}\text { Mengembangkan materi pembelajaran } \\
\text { yang diampu secara kreatif. }\end{array}$ \\
4 & $\begin{array}{l}\text { Mengembangkan keprofesionalan secara } \\
\text { berkelanjutan dengan melakukan } \\
\text { tindakan reflektif. }\end{array}$ \\
5 & $\begin{array}{l}\text { Memanfaatkan teknologi informasi dan } \\
\text { komunikasi untuk berkomunikasi dan } \\
\text { mengembangkan diri }\end{array}$ \\
\hline
\end{tabular}

Berdasarkan dari hasil observasi melalui diskusi secara langsung dengan salah seorang guru pamong PPL di SMPN 3 Rambah mengatakan bahwa masih banyak mahasiswa yang belum mampu menimbulkan sikap profesionalismenya menjadi seorang guru dan tidak menguasai tujuh kemampuan dalam mengajar di kelas sehingga kelas menjadi tidak terkendali. 
Permasalahan juga diperkuat dengan hasil wawancara dengan salah satu Dosen Pembimbing Lapangan (DPL) mahasiswa FKIP di SMPN 3 Rambah. Beliau mengatakan bahwa pemanfaatan teknologi dan media dalam pembelajaran sangat diperlukan untuk menunjang efektifitas belajar mengajar siswa disekolah, tetapi masih banyak dari mahasiswa PPL yang belum memanfaatkan teknologi dan media yang ada dalam proses belajar mengajar.

Kurang pahamnya mahasiswa dalam menguasai landasan kependidikan mengenai kurikulum yang digunakan di sekolah tersebut menyebabkan mahasiswa belum mampu untuk membuat perangkat pembelajaran, menyusun program pengajaran, melaksanakan program pengajaran dan mahasiswa PPL belum berani mengambil tindakan untuk menilai hasil dan proses belajar siswa yang sesuai dengan indikator keprofesionalan guru.

Dari latar belakang yang telah dijelaskan di atas maka peneliti tertarik melakukan penelitian dengan judul:

"Pengaruh Peranan Mata kuliah Profesi Kependidikan dan Microteaching terhadap Kompetensi Profesional Mahasiswa PPL Fisika FKIP Angkatan IV Universitas Pasir Pengaraian".

\section{METODE PENELITIAN}

Jenis penelitian yang dilakukan adalah penelitian deskriptif. Penelitian dilaksanakan pada Bulan Februari sampai dengan Maret 2017 pada Dosen Pembimbing Lapangan (DPL) yang membimbing 18 Mahasiswa Pendidikan Fisika. Penelitian ini dilaksanakan di Fakultas Keguruan dan Ilmu Pendidikan.

Populasi pada penelitian ini adalah DPL dengan jumlah 12 yang sedang membimbing 18 Mahasiswa Pendidikan Fisika. Desain penelitian ini menggunakan pendekatan Eks-post fakto. Variabel bebas dalam penelitian ini adalah mata kuliah profesi kependidikan dan microteaching. Variabel terikat dalam penelitian ini adalah kompetensi profesional.

Data sekunder dikumpulkan melalui data dokumentasi yang dilihat dari nilai akhir mahasiswa pendidikan fisika. Data primer dikumpulkan melalui penyebaran angket kepada DPL yang sedang membimbing mahasiswa pendidikan fisika. Setelah data dikumpulkan selanjutnya ditabulasi berdasarkan jawaban pada masing-masing item angket yang diberi skor dengan menggunakan skala bertingkat (rating scale). Lembar penilaian terdiri atas 3 alternatif jawaban (3, 2, dan 1), skor ini bersifat membedakan dan mengurutkan.

Analisis yang dilakukan adalah analisis korelasi product moment sebagai berikut:

$$
R_{x_{1} y}=\frac{\left(\sum X_{1} Y\right)}{\sqrt{\left(\sum X_{1}{ }^{2}\right)\left(\sum Y^{2}\right)}}
$$

$$
\begin{aligned}
& R_{x_{2} y}= \\
& \frac{\left(\sum X_{2} Y\right)}{\sqrt{\left(\sum X_{2}{ }^{2}\right)\left(\sum Y^{2}\right)}}
\end{aligned}
$$

$$
R_{y x_{1} x_{2}}=\sqrt{\frac{R^{2} y x_{1}+R^{2} y x_{2}-2 R_{y x_{1}} R_{y x_{2}} R_{x_{1} x_{2}}}{1-R^{2} x_{1} x_{2}}}
$$

Keterangan:

$$
\begin{aligned}
R_{y x_{1} x_{2}}= & \text { Korelasi antara variabel } \mathrm{X}_{1} \\
& \begin{array}{l}
\text { dengan } \mathrm{X}_{2} \text { secara bersama- } \\
\text { sama dengan variabel } \mathrm{Y}
\end{array} \\
R_{x_{1} y}= & \text { Koefisien korelasi antara } \\
& \text { variabel } \mathrm{X}_{1} \text { dan variabel } \mathrm{Y} \\
R_{x_{2} y}= & \text { Koefisien korelasi antara } \\
& \text { variabel } \mathrm{X}_{2} \text { dan variabel } \mathrm{Y} \\
R_{x_{1} x_{2}}= & \text { Koefisien korelasi antara } \\
& \text { variabel } \mathrm{X}_{1} \text { dan variabel } \mathrm{X}_{2} \\
\sum X_{1} Y= & \text { Jumlah produk } \mathrm{X}_{1} \text { terhadap } \mathrm{Y} \\
\sum X_{2} Y= & \text { Jumlah produk } \mathrm{X}_{2} \text { terhadap } \mathrm{Y} \\
\sum Y_{2}^{2}= & \text { Jumlah Kuadrat variabel } \mathrm{Y}
\end{aligned}
$$

(Sugiyono, 2012) 
Selanjutnya dilakukan penganalisaan terhadap hasil jawaban item pertanyaan dalam angket terbuka. Kemudian dilihat hubungan data angket, maka sebaran jawaban angket mahasiswa direkapitulasi berdasarkan kelompok jawaban responden dengan cara sebagai berikut (Riduwan, 2010):

Persentase skor $=\frac{\text { kelompok jawaban respoden }}{\text { skor tertinggi }} \times 100 \%$

Selanjutnya setelah dilakukan penskoran pada instrumen angket. Hasil akhir angket di totalkan nilainya secara keseluruhan pada setiap mata kuliah dengan menggunakan persamaan berikut (Astriana. W \& Sayuti, 2015):

$$
M=\frac{\sum F x}{N}
$$

$\mathrm{M}=$ Rata-rata skor

$\sum F x=$ Jumlah Skor yang diperoleh

$\mathrm{N}=$ Jumlah total pernyataan

(Sumber: Modifikasi Astriana, Syafi'I dan Sayuti, 2015).

Penelitian yang menunjukkan adanya korelasi yang signifikan perlu dicari besarnya kontribusi variabel $\mathrm{X}$ terhadap variabel $Y$. Untuk melihat besarnya kontribusi variabel $\mathrm{X}$ terhadap variabel $\mathrm{Y}$ dapat digunakan rumus koefisien determinan sebagai berikut:

$$
R=\left(R_{y x_{1}}\right)^{2} \times 100 \%
$$

$$
R=\left(R_{y x_{1}}\right)^{2} \mathrm{x}
$$

$100 \%$

(Sundayana, 2010)

$R_{y(1,2)}^{2}=\left(R_{y x_{1} x_{2}}\right)^{2} \times 100 \%$

(6)

(Hartono, 2004)
Keterangan :

$\mathrm{R}=$ Koefisien Determinasi

$R_{y(1,2)}^{2} \quad=$ koefisien determinasi ganda

pengaruh $\mathrm{X}_{1}, \mathrm{X}_{2}$ terhadap $\mathrm{Y}$

$\mathrm{Ryx}_{1}=$ Jumlah produk antara $\mathrm{X}_{1}$ terhadap Y

$\operatorname{Ryx}_{2}=$ Jumlah produk antara $X_{2}$ terhadap Y

$\left(R_{y x_{1} x_{2}}\right)^{2}=$ Jumlah produk antara $\mathrm{X}_{1}$ dan $\mathrm{X}_{2}$ terhadap $\mathrm{Y}$

\section{HASIL DAN PEMBAHASAN}

Hasil korelasi berdasarkan perhitungan nilai akhir mata kuliah profesi kependidikan dan microteaching terhadap nilai akhir PPL dapat dilihat pada tabel. 1 berikut:

Tabel 3. Pengaruh Mata Kuliah Profesi Kependidikan dan Micro teaching terhadap Kompetensi Profesional

\begin{tabular}{|c|c|c|c|}
\hline $\begin{array}{c}\text { Aspek } \\
\text { Korelasi }\end{array}$ & $\begin{array}{c}\text { Nilai } \\
\text { Korelasi }\end{array}$ & $\begin{array}{c}\mathbf{F} \\
\text { Tabel }\end{array}$ & Interpretasi \\
\hline $\begin{array}{l}\text { Nilai akhir } \\
\mathrm{X}_{1} \mathrm{Y}\end{array}$ & $0,98^{*}$ & & Sangat Tinggi \\
\hline $\begin{array}{l}\text { Nilai Akhir } \\
\mathrm{X}_{2} \mathrm{Y}\end{array}$ & $0,98^{*}$ & 0,46 & Sangat Tinggi \\
\hline $\begin{array}{l}\text { Nilai Akhir } \\
\mathbf{X}_{1} \mathbf{X}_{2} \mathbf{Y}\end{array}$ & $1,00^{*}$ & & Sangat Tinggi \\
\hline
\end{tabular}
Mahasiswa PPL Angkatan IVberdasar nilai akhir

Hasil analisis perhitungan data dilakukan dengan menggunakan rumus korelasi product moment adalah sebesar 1,00. Sehingga interpretasi terhadap 18 mahasiswa, diperoleh $(r$ tabel $)$ pada taraf signifikan 5\% sebesar 0,46 Maka telah diketahui nilai $r_{\text {hitung }}$ adalah sebesar 1,00, sedangkan nilai $r_{\text {tabel }}$ masing-masing sebesar 0,46. Dengan demikian rhitung lebih besar dari $r_{\text {tabel }}\left(r_{\text {hitung }}>r_{\text {tabel }}\right)$. Maka terdapat korelasi yang sangat tinggi antara mata kuliah profesi kependidikan dan micro teaching terhadap PPL.

Untuk mengetahui perbandingan angka korelasi mahasiswa pada mata 
kuliah profesi kependidikan dan micro teaching (Variabel $\mathrm{X}_{1}$ dan $\mathrm{X}_{2}$ ) terhadap PPL (Variabel Y) berdasarkan nilai akhir dapat dilihat pada Gambar 1 berikut:

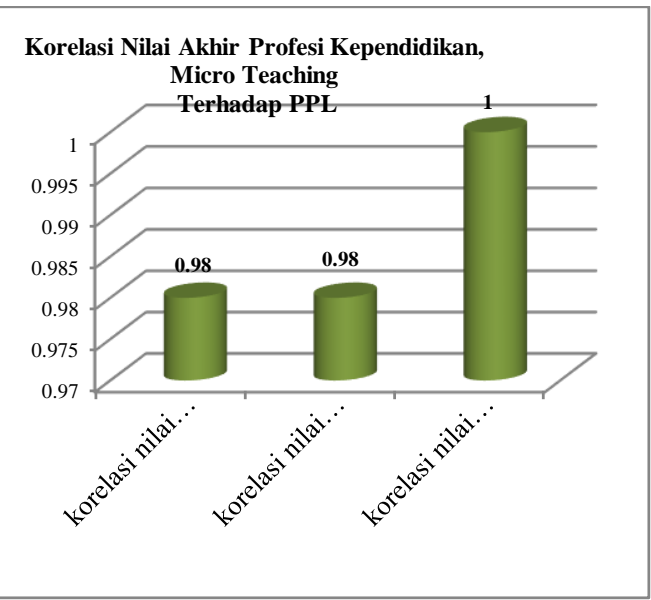

Gambar 1. Grafik perbandingan tata-rata Angka korelasi nilai akhir mata kuliah profesi kependidikan, microteaching terhadap PPL

Profesi menurut (Soetjipto \& K, 2004) adalah pekerjaan yang memerlukan bidang ilmu dan keterampilan tertentu di luar jangkauan khalayak ramai (tidak semua orang dapat melakukannya). Profesi menurut Rusman adalah suatu jabatan atau pekerjaan yang menuntut keahlian tertentu (Rusman, 2012). Profesi Keguruan adalan pekerjaan yang dilakukan oleh seseorang untuk membimbing seseorang menjadi manusia yang berkualitas dengan pendidikan yang baik.

Dalam mata kuliah profesi kependidikan mahasiswa diajarkan untuk menguasai kode etik keguruan, dan bersikap sebagai seorang guru yang menguasai kompetensi dasar seorang guru, termasuk ke dalamnya adalah kompetensi profesional.

Microteaching dapat diartikan sebagai cara latihan keterampilan mengajar guru atau praktik mengajar guru dalam lingkup kecil/terbatas. Jadi dapat dipahami bahwa microteaching adalah model pengajaran yang dikecilkan atau disebut juga dengan real teaching $(\mathrm{Z}$,
2012). Dalam mata kuliah microteaching mahasiswa diarahkan untuk menjadi seorang guru yang mampu dan menguasai materi bidang studi, mengelola kelas, memahami standar kompetensi dan kompetensi dasar sehingga dalam merancang rencana pembelajaran sesuai dan mencapai tujuan yang diinginkan.

Tabel 4. koefisien determinasi variabel $X_{1}$ terhadap $\mathrm{Y}, \mathrm{X}_{2}$ terhadap $\mathrm{Y}$ dan $\mathrm{X}_{1} \mathrm{X}_{2}$ terhadap Y

\begin{tabular}{ccc}
\hline No. & Aspek Korelasi & Determinasi \\
\hline 1 & Nilai akhir $\mathrm{X}_{1} \mathrm{Y}$ & $96,04 \%$ \\
2 & Nilai Akhir $\mathrm{X}_{2} \mathrm{Y}$ & $96,04 \%$ \\
3 & Nilai Akhir $\mathrm{X}_{1} \mathrm{X}_{2} \mathrm{Y}$ & $100 \%$ \\
\hline
\end{tabular}

Berdasarkan Tabel 4 di atas dapat dilihat bahwa hasil perhitungan koefisien determinasi pada mata kuliah profesi kependidikan dan microteaching terhadap PPL masing masing memiliki nilai determinasi mencapai $100 \%$, sehingga dapat disimpulkan bahwa sumbangan persentase dari mata kuliah profesi kependidikan dan microteaching terhadap PPL sangat tinggi.

Berdasarkan data untuk variabel $\mathrm{X}_{1}$, $\mathrm{X}_{2}$ dan variabel $\mathrm{Y}$ yang terkumpul dari penyebaran angket pada 12 DPL yang membimbing 18 mahasiswa fisika dengan jumlah pernyataan masing-masing mata kuliah 15 butir instrumen pernyataan, maka dapat diketahui persentase skor masing-masing indikator sebagai berikut:

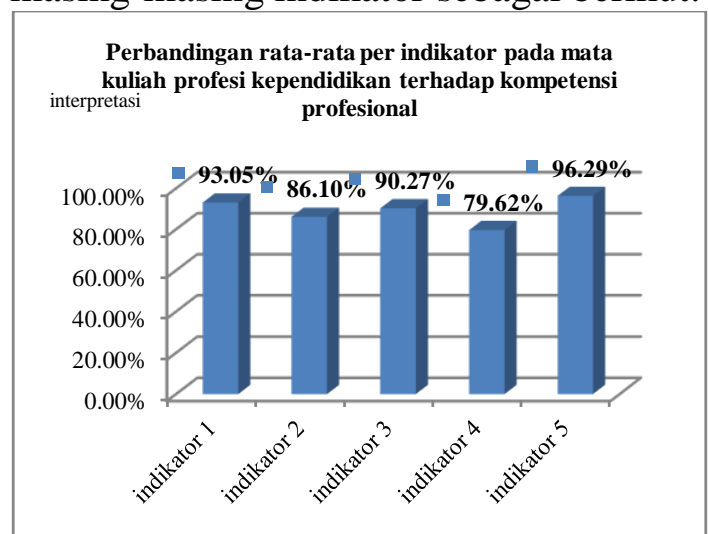

Gambar 2. Grafik perbandingan rata-rata per indikator pada mata kuliah profesi kependidikan terhadap kompetensi profesional 
Hasil perhitungan angket untuk mata kuliah microteaching terhadap kompetensi profesional dapat diketahui persentase skor masing-masing indikator adalah sebagai berikut:

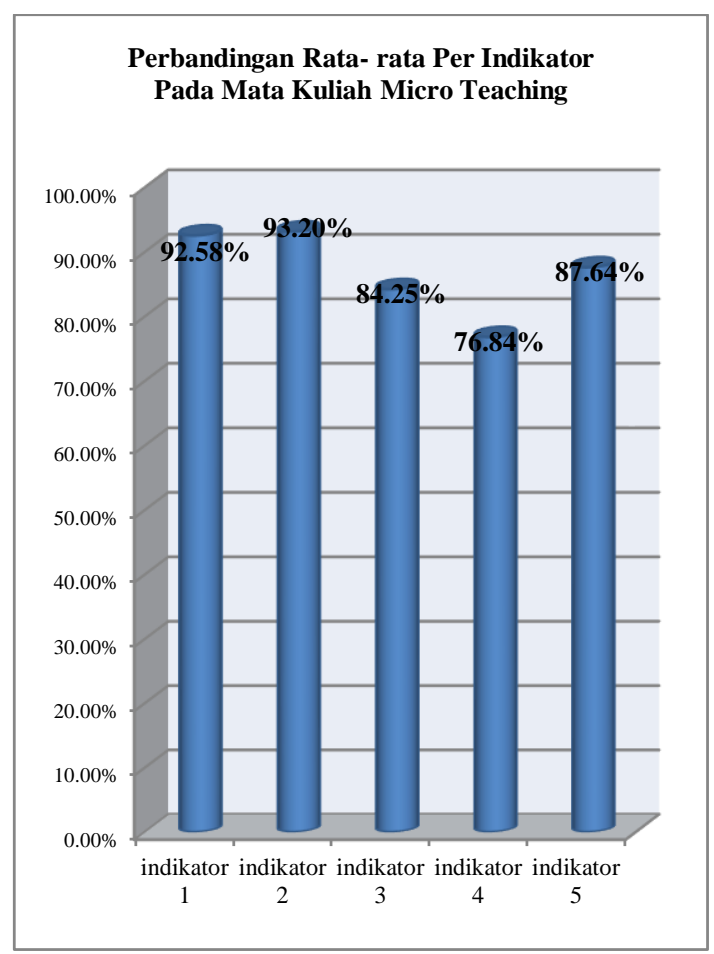

Gambar 3. Grafik Perbandingan Rata-rata per indikator pada mata kuliah micro teaching terhadap kompetensi profesional

Jika dilihat berdasarkan Gambar 2 dan Gambar 3 menyatakan bahwa responden (DPL) mahasiswa fisika telah memenuhi syarat kompetensi profesional dengan jumlah persentase hasil angket mencapai $96,29 \%$ tertinggi dan 76,84\% terendah namun masih dalam kategori sangat kuat dan kuat.

Berdasarkan hasil penyebaran angket kepada DPL pengaruh mata kuliah profesi kependidikan dan microteaching terhadap kompetensi profesional secara keseluruhan variabel $\mathrm{X}_{1}, \mathrm{X}_{2}$ terhadap variabel $\mathrm{Y}$ adalah sebagai berikut:
Tabel 5. Pengaruh Mata Kuliah Profesi

Kependidikan dan Micro teaching terhadap Kompetensi Profesional Mahasiswa PPL Angkatan IV berdasar instrumen angket

\begin{tabular}{|c|c|c|c|}
\hline $\begin{array}{c}\text { Aspek } \\
\text { Korelasi }\end{array}$ & $\begin{array}{c}\text { Nilai } \\
\text { Korelasi }\end{array}$ & $\begin{array}{c}\begin{array}{c}\mathbf{F} \\
\text { Tabel }\end{array} \\
5 \% \\
\end{array}$ & Interpretasi \\
\hline $\begin{array}{l}\text { Nilai } \\
\text { angket } \\
\mathrm{X}_{1} \mathrm{Y}\end{array}$ & $0,99^{*}$ & & Sangat Tinggi \\
\hline $\begin{array}{l}\text { Nilai } \\
\text { angket } \\
\mathrm{X}_{2} \mathrm{Y}\end{array}$ & $0,97^{*}$ & 0,46 & Sangat Tinggi \\
\hline $\begin{array}{l}\text { Nilai } \\
\text { angket } \\
\mathrm{X}_{1} \mathrm{X}_{2} \mathrm{Y}\end{array}$ & $1,00^{*}$ & & Sangat Tinggi \\
\hline
\end{tabular}

Hasil analisis perhitungan data dilakukan dengan menggunakan rumus korelasi product moment adalah sebesar 1,00. Sehingga interpretasi terhadap 18 mahasiswa, diperoleh $(r$ tabel $)$ pada taraf signifikan 5\% sebesar 0,46 Maka telah diketahui nilai $\mathrm{r}_{\text {hitung }}$ adalah sebesar 1,00, sedangkan nilai $r_{\text {tabel }}$ masing-masing sebesar 0,46. Dengan demikian rhitung lebih besar dari $r_{\text {tabel }}\left(r_{\text {hitung }}>r_{\text {tabel }}\right)$. Maka terdapat korelasi yang sangat tinggi antara mata kuliah profesi kependidikan dan microteaching terhadap PPL.

Untuk mengetahui perbandingan angka korelasi mahasiswa pada mata kuliah profesi kependidikan dan microteaching (Variabel $\mathrm{X}_{1}$ dan $\mathrm{X}_{2}$ ) terhadap PPL (Variabel Y) berdasarkan nilai akhir angket dapat dilihat pada Gambar 4 berikut:

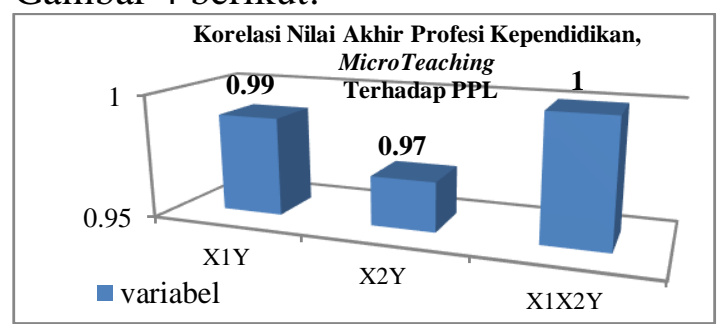

Gambar 4. korelasi nilai akhir angket profesi kependidikan, micro teaching terhadap kompetensi profesional 
Berdasarkan Gambar 4 dapat disimpulkan korelasi nilai akhir instrumen angket pada mata kuliah profesi kependidikan dan microteaching terhadap kompetensi profesional termasuk ke dalam kategori sangat tinggi.

Hamalik menjelaskan bahwa masalah kompetensi profesional guru merupakan salah satu dari kompetensi yang harus memiliki oleh setiap guru dalam jenjang Pendidikan (Oemar, 2010). Namun, kompetensi lainnya tidak boleh diabaikan yaitu kompetensi pedagogik, kompetensi kepribadian dan kompetensi sosial. Kompetensi profesional merupakan kemampuan, keahlian, kecakapan dasar tenaga pendidik yang harus dikuasai dalam melaksanakan tugasnya sebagai guru (Janawi, 2011).

Indikator dari kompetensi profesional menurut (Marno \& Idris, 2009) kompetensi profesional mempunyai pengertian sebagai kewenangan yang berhubungan dengan tugas mengajar yang mencakup: (1) penguasaan pada bidang studi yang diajarkan, (2) memahami keadaan diri siswa, (3) memahami prinsip-prinsip dan teknik mengajar, (4) menguasai cabang-cabang ilmu pengetahuan yang relevan dengan bidang studinya, dan (5) menghargai profesinya.

Sumbangan persentase variabel $\mathrm{X}_{1}$ dan $\mathrm{X}_{2}$ terhadap variabel $\mathrm{Y}$ dapat dilihat pada Tabel 4 berikut:

Tabel 6. Koefisien determinasi variabel $X_{1}$ terhadap $\mathrm{Y}, \mathrm{X}_{2}$ terhadap $\mathrm{Y}$ dan $\mathrm{X}_{1} \mathrm{X}_{2}$ terhadap $\mathrm{Y}$

\begin{tabular}{ccc}
\hline No. & Aspek Korelasi & Determinasi \\
\hline 1 & Nilai akhir $\mathrm{X}_{1} \mathrm{Y}$ & $98,01 \%$ \\
2 & Nilai Akhir $\mathrm{X}_{2} \mathrm{Y}$ & $94,09 \%$ \\
3 & Nilai Akhir & $100 \%$ \\
& $\mathrm{X}_{1} \mathrm{X}_{2} \mathrm{Y}$ & \\
\hline & &
\end{tabular}

Berdasarkan Tabel 6 di atas dapat disimpulkan bahwa sangat besar pengaruh mata kuliah profesi kependidikan dan micro teaching terhadap kompetensi profesional, sumbangan persentase kedua mata kuliah mencapai $100 \%$ dengan kategori sangat tinggi. Kompetensi profesional sendiri didapatkan seorang guru melalui pendidikan dan diaplikasikan dalam kegiatan mengajarnya. Seorang guru yang profesional diwajibkan memahami kode etik profesi guru yang tercantum di dalam Kode Etik Guru Indonesia (Pemerintah, n.d.) (Revisi Kode Etik keputusan kongres XXI PGRI Nomor: VI/Kongres/XXI/PGRI/2013), yang terdiri dari 8 pasal yaitu (1) kewajiban umum, (2) kewajiban guru terhadap peserta didik, (3) kewajiban guru terhadap orang tua/ wali peserta didik, (4) kewajiban guru terhadap masyarakat, (5) kewajiban guru terhadap Teman sejawat, (6) Kewajiban guru terhadap profesi, (7) kewajiban guru terhadap organisasi profesi, dan (8) kewajiban guru terhadap pemerintah.

Sikap profesionalisme mengarah kepada komitmen para anggota suatu profesi untuk meningkatkan kemampuan profesionalnya dan terus-menerus mengembangkan strategi-strategi yang digunakannya dalam melakukan pekerjaan yang sesuai dengan profesi yang diembannya. Guru yang profesional adalah guru yang memiliki kompetensi yang dipersyaratkan untuk melakukan tugas pendidikan dan pembelajaran (Rusman, 2012).

Kompetensi yang dipersyaratkan salah satunya kompetensi profesional, jika dilihat dari hasil penelitian menyatakan bahwa mahasiswa fisika yang telah melakukan PPL telah memenuhi indikator kompetensi profesional dengan kategori sangat baik.

\section{SIMPULAN DAN SARAN}

Berdasarkan hasil analisis data mengenai pengaruh peranan mata kuliah profesi kependidikan dan microteaching terhadap kompetensi profesional yang dilaksanakan di lingkungan FKIP 
Universitas Pasir Pengaraian didapat hasil yaitu:

1. Pengaruh peranan mata kuliah profesi kependidikan dan microteaching terhadap kompetensi profesional berdasarkan nilai akhir setiap mata kuliah ditunjukkan dengan perhitungan menggunakan korelasi Product Moment yaitu sebesar 0,98, 0,98 dan 1 dalam kategori sangat kuat dan memiliki pengaruh yang sangat positif dan signifikan. Sedangkan berdasarkan perhitungan koefisien determinasi, sumbangan persentase setiap mata kuliah terhadap kompetensi profesional berada dalam kategori sangat tinggi.

2. Pengaruh peranan mata kuliah profesi kependidikan dan microteaching terhadap kompetensi profesional berdasarkan nilai angket setiap mata kuliah ditunjukkan dengan perhitungan menggunkan korelasi product moment yaitu sebesar 0,99, 0,97 dan 1 dalam kategori sangat kuat dan memiliki pengaruh yang sangat positif dan signifikan. Sedangkan berdasarkan perhitungan koefisien determinasi, sumbangan persentase setiap mata kuliah terhadap kompetensi profesional berada dalam kategori sangat tinggi.

Berdasarkan hasil penelitian yang telah dilakukan untuk melihat pengaruh mata kuliah profesi kependidikan dan microteaching terhadap kompetensi profesional mahasiswa PPL fisika angkatan IV, adapun saran dan rekomendasi peneliti, sebagai berikut:

1. Bagi mahasiswa yang mengambil mata kuliah profesi kependidikan dan microteaching agar diharapkan mampu untuk mengikuti perkuliahan tersebut dengan baik dikarenakan mata kuliah profesi kependidikan dan microteaching merupakan syarat untuk mengambil mata kuliah PPL. Sehingga dalam melaksanakan PPL mahasiswa tidak mengabaikan kode etik sebagai calon guru dan mampu melaksanakan PPL dengan baik.

2. Bagi peneliti selanjutnya yang ingin melakukan penelitian tentang pengaruh mata kuliah syarat PPL terhadap kompetensi profesional, dapat mengambil syarat mata kuliah lainnya yaitu, pengantar pendidikan, perkembangan peserta didik dan belajar danpembelajaran. Dan juga diharapkan dapat secara langsung bertanya dan dalam mengambil sampel penelitian selain DPL juga dapat menghadap kepada guru pamong PPL.

\section{DAFTAR PUSTAKA}

Astriana. W, S. W., \& Sayuti, I. (2015). Pengembangan Lembar Kerja Siswa (LKS) pada Materi Sistem Pencernaan Kelas VIII SMP dengan Pendekatan Saintifik. Jurnal.

Hartono. (2004). Stastistik Untuk Penelitian. Pekanbaru: Lembaga Studi Filsafat, Kemasyarakatan, Kependidikan dan Perempuan (LSFK2P).

Hendrayani, R. (2008). Mengembangkan Kompetensi Personal Mahasiswa Pendidikan Ekonomi Sebagai Calon Guru Melalui Soft Competency Training. Dinamika Pendidikan, $3(2)$.

Janawi. (2011). Kompetensi Guru Citra Guru Profesional. Bandung: Alfabeta.

Marno, \& Idris, M. (2009). Strategi dan Metode Pengajaran. Jogjakarta: Arruzz Media.

Muhroji, M. M., \& Setyanto, C. B. (2016). Model Pengelolaan Program Pengalaman Lapangan Program Studi Guru Sekolah Dasar Fkip UMS. Profesi Pendidikan Dasar, 1(2), 149-161. 
Oemar, H. (2010). Pendidikan Guru Berdasarkan Pendekatan Kompetensi. Jakarta: Bumi Aksara.

Pemerintah. (n.d.). Keputusan Kongres XXI Persatuan Guru Republik Indonesia Nomor: VI/Kongres/XXI/PGRI/2013 tentang Kode Etik Guru Indonesia.

Riduwan. (2010). Skala Pengukuran variable-variabel penelitian. Bandung: Alfabeta.

Rusman. (2012). Belajar dan Pembelajaran Berbasis Komputer Mengembangkan Profesionalisme Guru Abad 21. Bandung: Alfabeta.

Soetjipto, \& K, R. (2004). Profesi Keguruan. Jakarta: Renika Cipta.

Sugiyono. (2012). Metode Penelitian Pendidikan pendekatan kuantitatif, kualitatif, dan $R$ \& D. Bandung: Alfabeta.

Suherman, A. (2014). Pengembangan Model Program Pelatihan Profesi untuk Meningkatkan Kompetensi Pedagogis Mahasiswa PGSD Penjas. Jurnal Cakrawala Pendidikan, 1(1).

Sundayana, R. (2010). Statistika Penelitian Kualitatif. Garut: STKIP Garut Press.

Tim Revisi. (2016). Buku Panduan Praktek Pengalaman Lapangan (PPL) Edisi Revisi. Unit Program Pengalaman Lapangan. Fakultas Keguruan Dan Ilmu Pendidikan. Universitas Pasir Pengaraian.

Yamin, M. (2007). Profesionalisasi Guru dan Implementasi KTSP. Jakarta: Gaung Persada Press.

Z, A. (2012). Micro teaching Disertai Dengan Pedoman Pengalaman Lapangan. Jakarta: Raja Grafindo Persada. 